\title{
Coulisses
}

Revue de théâtre

10 | Printemps 1994

Varia

\section{Retour sur un colloque : «L'acteur en son métier »}

\section{Philippe Baron}

\section{OpenEdition}

Journals

Édition électronique

URL : http://journals.openedition.org/coulisses/3162

DOI : $10.4000 /$ coulisses.3162

ISSN : 2546-9460

\section{Éditeur}

Presses universitaires de Franche-Comté

\section{Édition imprimée}

Date de publication : 1 juin 1994

Pagination : 82

ISSN : 1150-594X

\section{Référence électronique}

Philippe Baron, « Retour sur un colloque : «L'acteur en son métier » », Coulisses [En ligne], 10 |

Printemps 1994, mis en ligne le 15 mars 2019, consulté le 31 octobre 2019. URL : http://

journals.openedition.org/coulisses/3162 ; DOI : 10.4000/coulisses.3162

Ce document a été généré automatiquement le 31 octobre 2019

Coulisses 


\title{
Retour sur un colloque : « L'acteur en son métier»
}

\author{
Philippe Baron
}

1 Le colloque a eu lieu le 4 décembre 1993 à Dijon. Il était organisé, sous les auspices du centre Littératures et arts du spectacle, dirigé par Francis Claudon, professeur de Littérature comparée, par Didier Souiller, également professeur de Littérature comparée et par moi-même.

2 Le but de ce colloque était d'étudier l'évolution de l'art de l'acteur depuis l'antiquité jusqu'à nos jours. Deux ateliers furent constitués. L'atelier I dirigé par Didier Souiller travailla sur les périodes les plus anciennes. Je m'occupais de l'atelier II où était réunis des spécialistes du XIX ${ }^{\text {ème }}$ et XXème siècle.

3 Toutes les communications mériteraient d'être citées. Je n'en rappellerai que quelquesunes. Fernande Bassan présenta les grands acteurs romantiques, Bocage, Frederick Lemaître, Marie Dorval. Shinobu Chujo expliqua en quoi consistait le jeu de l'acteur du nô, genre théâtral seulement à demi-connu par les Français. Jacques Houriez montra que Claudel recherche surtout chez l'acteur « un geste stylisé, la musicalité de la voix, le rayonnement de la personne ». Michel Autrand s'interrogea sur les rapports subtils qui unissent l'auteur et l'interprète à la lumière de l'exemple d'Eve Francis et de Claudel. Nielle Guibert, bibliothécaire de la Comédie-Française, clôtura la journée. Elle partit des traités de Chappuzeau et de d'Aubignac pour arriver à l'époque actuelle ; elle rappela que la pièce tend maintenant à échapper à l'acteur pour passer sous l'autorité du metteur en scène; elle conclut sur l'importance du mouvement et du travail en groupe dans le théâtre moderne.

4 Les actes du colloque doivent paraitre chez Klircksieck. 